\title{
Isbath Nikah Perkawinan Sirri Ditinjau dari Undang-Undang Nomor 16 Tahun 2019 Tentang Perubahan atas Undang-Undang Nomor 1 Tahun 1974 Tentang Perkawinan dan Kompilasi Hukum Islam
}

\author{
Fauzia Dwianti Nugraha*, Lina Jamilah \\ Indonesia. \\ *fauziadwianti@yahoo.com, linajamilah62@gmail.com
}

Prodi Ilmu Hukum, Fakultas Hukum, Universitas Islam Bandung,

\begin{abstract}
Marriage itsbat is the determination of a legal sirri marriage by the Religious Courts to obtain a marriage certificate. Married couples in Purwakarta who have had a sirri marriage and do not yet have a marriage certificate can perform marriage itsbat which is funded by the Local Government of Purwakarta Regency, such as in Maniis and Bojong sub-districts. This study aims to determine the implementation of marriage itsbat sirri marriage in Purwakarta and how the legal protection marriage of itsbat to the people in Purwakarta. The research method used in this research was the JuridicalNormative method and the library data collection technique by using secondary data consisting of primary legal materials and secondary legal materials. The results showed that the implementation of itsbat marriage in Maniis District and Bojong District, Purwakarta Regency was by following under Article 7 paragraph (3) of the KHI and did not violate the marriage restrictions of Article 8 of the Marriage Law. However, for the witnesses who were present at the marriage itsbat trial, there was still a misunderstanding, namely that the witnesses presented did not have to be witnesses in the marriage contract. Legal protection in the implementation of itsbat marriage is the birth of a marriage certificate as authentic evidence that a legal marriage has occurred which has legal consequences for husband and wife, children, and assets.
\end{abstract}

Keywords: Legal marriage, Sirri marriage, Marriage itsbat.

\begin{abstract}
Abstrak. Itsbat nikah merupakan penetapan perkawinan sirri yang sah oleh Pengadilan Agama untuk mendapatkan akta nikah. Pasangan suami-isteri di purwakarta yang sudah melakukan perkawinan sirri dan belum mempunyai akta nikah dapat melakukan itsbat nikah yang dibiayai oleh pemerintah daerah kabupaten Purwakarta seperti di kecamatan Maniis dan kecamatan Bojong. Penelitian ini bertujuan untuk mengetahui implementasi itsbat nikah perkawinan sirri di Purwakarta dan bagaimana perlindungan hukum dari itsbat nikah terhadap masyarakat Purwakarta. Metode penelitian yang digunakan dalam penelitian yaitu metode Yuridis-Normatif dan teknik pengumpulan data secara kepustakaan dengan menggunakan data-data sekunder yang terdiri dari bahan hukum primer dan bahan hukum sekunder. Hasil penelitian bahwa implementasi itsbat nikah di Kecamatan Maniis dan Kecamatan Bojong Kabupaten Purwakarta sudah sesuai dengan Pasal 7 ayat (3) Kompilasi Hukum Islam dan tidak melanggar halangan perkawinan Pasal 8 Undang-Undang Perkawinan. Namun untuk saksi yang hadir dalam persidangan itsbat nikah masih terjadi kesalahpahaman dalam hal saksi yang dihadirkan tidak harus saksi dalam akad nikah. Perlindungan hukum dilaksanakannya itsbat nikah adalah terlahirnya akta nikah sebagai bukti otentik telah terjadinya perkawinan sah yang membawa akibat hukum terhadap suami-isteri, anak, dan harta kekayaan.
\end{abstract}

Kata Kunci: Perkawinan sah, Perkawinan sirri, Itsbat nikah. 


\section{A. Pendahuluan}

Masyarakat Indonesia hidup dalam keragaman atau pluralisme hukum, oleh sebab itu masyarakatnya harus tunduk terhadap 3 (tiga) hukum yaitu hukum adat, hukum agama, dan hukum nasional. Pluralisme hukum juga terdapat di dalam perkawinan. Konsekuensi dari Perkawinan yang dijalankan hanya berdasarkan salah satu hukum dan mengabaikan hukum lainnya yaitu akan menimbulkan dampak terhadap legalitas perkawinan baik dari hukum adat, agama, dan nasional. Undang-Undang Nomor 16 Tahun 2019 Tentang Perubahan Atas UndangUndang Nomor 1 Tahun 1974 Tentang Perkawinan (Undang-Undang Perkawinan) merupakan suatu unifikasi yang unik dengan menghormati secara penuh terhadap agama, dan kepercayaanya yang berketuhunan Yang Maha Esa. Keberagaman Hukum dibuktikan dalam Pasal 2 ayat (1) dan Pasal 2 ayat (2) berkenaan dengan perkawinan sah bila dilakukan berdasarkan hukum masing-masing agama dan kepercayaanya, lalu setiap perkawinan harus dicatatat. Perkawinan yang tidak dicatat disebut juga dengan perkawinan sirri, perkawinan tersebut hanya sah berdasarkan agama. Pencatatan perkawinan berlaku juga untuk pengesahan perkawinan yang ditetapkan oleh pengadilan sesuai dengan Kompilasi Hukum Islam.

Pemerintah Kabupaten Purwakarta membuat suatu program itsbat nikah gratis yang bekerjasama dengan Pengadilan Agama Purwakarta. Hal tersebut sebagai salah satu bentuk pelayanan terhadap masyarakat bagi mereka yang belum memiliki akta nikah, karena di Purwakarta masih banyak masyarakatnya yang belum memiliki akta nikah yang disebabkan oleh minimnya informasi mengenai pentingnya akta nikah, pernikahan usia dini, dan faktor ekonomi yang menjadikan masyarakat mengabaikan administrasi perkawinan.

Dalam pelaksanaanya bagi masyarakat Purwakarta yang belum mempunyai akta nikah atau dokumen perkawinan boleh mengikuti program itsbat nikah gratis dan tidak ada batasannya selama kuota yang ditargetkan masih ada. Namun, dalam Kompilasi Hukum Islam Pasal 7 ayat (3) terdapat batasan dalam pelaksanaan itsbat nikah.

Berdasarkan latar belakang yang telah diuraikan, maka perumusan masalah dalam penelitian ini adalah

1. Bagaimana itsbat nikah perkawinan sirri di Purwakarta ditinjau dari Undang-Undang Nomor 16 Tahun 2019 Tentang Perubahan Atas Undang-Undang Nomor 1 Tahun 1974 Tentang Perkawinan dan Kompilasi Hukum Islam?

2. Bagaimana perlindungan hukum dari itsbat nikah perkawinan sirri terhadap masyarakat Purwakarta ditinjau dari Undang-Undang Nomor 16 Tahun 2019 Tentang Perubahan Atas Undang-Undang Nomor 1 Tahun 1974 Tentang Perkawinan dan Kompilasi Hukum Islam?

Selanjutnya, tujuan dari penelitian ini yaitu :

1. Untuk mengetahui implementasi dari itsbat Nikah perkawinan sirri di Purwakarta ditinjau dari Undang-Undang Nomor 16 Tahun 2019 Tentang Perubahan Atas UndangUndang Nomor 1 Tahun 1974 Tentang Perkawinan dan Kompilasi Hukum Islam.

2. Untuk mengetahui perlindungan hukum dari Itsbat Nikah Perkawinan Sirri terhadap Masyarakat di Purwakarta ditinjau dari Undang-Undang Nomor 16 Tahun 2019 Tentang Perubahan Atas Undang-Undang Nomor 1 Tahun 1974 Tentang Perkawinan dan Kompilasi Hukum Islam.

\section{B. Landasan Teori}

Berdasarkan Undang-Undang Perkawinan, perkawinan ialah ikatan lahir bathin antara seorang pria dengan seorang wanita sebagai suami isteri dengan tujuan membentuk keluarga (rumah tangga) yang bahagia dan kekal berdasarkan Ketuhanan Yang Maha Esa. Perkawinan tersebut sah apabila dilakukan berdasarkan hukum masing-masing agama dan kepercayaanya, lalu dilakukan pencatatan atas perkawinannya tersebut.

Menurut Prof. Scholten menyebutkan "perkawinan adalah suatu hubungan hukum antara seorang pria dengan seorang wanita untuk hidup bersama dengan kekal, yang diakui oleh negara". Menurut Ali Afandi "menurut Kitab Undang-undang Hukum Perdata, perkawinan adalah persatuan seorang laki-laki dan perempuan secara hukum untuk hidup bersama-sama. Hidup bersama ini dimaksudkan untuk berlangsung selama-lamanya”. Syarat-syarat perkawinan 
menurut Undang-Undang Perkawinan yaitu :

1. Syarat-syarat sahnya perkawinan secara materiil

a. Harus berdasarkan atas persetujuan dari kedua calon mempelai.

b. Perkawinan diizinkan apabila pria dan wanita mencapai umur 19 tahun.

c. Calon mempelai tidak sedang terikat dalam hubungan perkawinan dengan orang lain.

d. Calon mempelai tidak dalam hubungan darah/keluarga yang tidak boleh kawin.

e. Bagi seorang wanita sudah pernah menikah dan putus perkawinannya terdapat jangka waktu tunggu.

2. Syarat-syarat Formil sahnya perkawinan

Syarat dan tata cara dalam melangsungkan perkawinan diatur dalam Peraturan Pemerintah Nomor 9 Tahun 1975 Tentang Pelaksanaan Undang-Undang Nomor 1 Tahun 1974 Tentang Perkawinan terdapat yaitu :

a. Pemberitahuan

Dalam Pasal 3 ayat (1) Undang-Undang Perkawinan :

"Setiap orang yang akan melangsungkan perkawinan memberitahukan kehendaknya itu kepada Pegawai Pencatat ditempat perkawinan akan dilangsungkan."

Pasal 3 ayat (2) Undang-Undang Perkawinan :

"Pemberitahuan tersebut dalam ayat (1) dilakukan sekurang-kurangnya 10 (sepuluh) hari kerja sebelum perkawinan dilangsungkan."

Pasal 4 Undang-Undang Perkawinan :

"Pemberitahuan dilakukan secara lisan atau tertulis oleh calon mempelai atau oleh orang tua atau wakilnya."

b. Penelitian

Dalam Pasal 6 ayat (1) Undang-Undang Perkawinan :

"Pegawai pencatat yang menerima pemberitahuan kehendak melangsungkan perkawinan, meneliti apakah syarat-syara perkawinan telah dipenuhi dan apakah tidak terdapat halangan perkawinan menurut Undang-Undang."

c. Pengumuman

Berdasarkan Pasal 8 Undang-Undang Perkawinan :

"Setelah dipenuhinya tata cara dan syarat-syarat pemberitahuan serta tiada suatu halangan perkawinan, Pegawai pencatat menyelenggarakan pengumuman tentang pemberitahuan kehendak melangsungkan perkawinan dengan cara menempelkan surat pengumuman tentang pemberitahuan kehendak melangsungkan perkawinan dengan cara menempelkan surat pengumuman menurut formular yang ditetapkan pada kantor Pencatatan Perakawinan pada suatu tempat yang sudah ditentukan dan mudah dibaca oleh umum."

d. Pelaksanaan

Berdasarkan Pasal 10 Undang-Undang Perkawinan :

1) "Pekawinan dilangsungkan setelah hari kesepuluh sejak pengumuman kehendak perkawinan oleh Pegawai Pencatat seperti yang dimaksud dalam Pasal 8 Peraturan Pemerintah ini.

2) Tata cara perkawinan dilakukan menurut hukum masing-masing agamanya dan kepercayaanya itu.

3) Dengan mengindahkan tata cara perkawinan menurut masing-masing agamanya dan kepercayaanya itu, perkawinan dilaksanakan dihadapan Pegawai Perncatat dan dihadiri oleh dua orang saksi."

Dalam Pasal 3 Kompilasi Hukum Islam menjelaskan mengenai tujuan perkawinan yaitu untuk mewujudkan rumah tangga sakinah, mawaddah dan rahmah. Maksudnya, ialah rumah tangga yang tentram, penuh kasih sayang, serta bahagia lahir dan batin. Kemudian, terdapat rukun dan syarat perkawinan pada Kompilasi Hukum Islam Pasal 14 yang menyebutkan : untuk melaksanakan perkawinan harus ada calon suami, calon isteri, wali nikah, dua orang saksi, dan ijab dan Kabul. Dalam kompilasi hukum islam juga terdapat akibat perkawinan terhadap hak 
dan kewajiban antara suami dan isteri, orang tua dan anak, dan harta kekayaan dalam perkawinan.

Dalam Kompilasi Hukum Islam juga terdapat asas-asas hukum mengenai perkawinan yaitu :

1. Asas untuk selama-lamanya

2. Asas kemaslahatan hidup

3. Asas kepastian hukum

4. Asas persetujuan

5. Asas kebebasan

6. Asas kemitraan suami-isteri

Republik Indonesia Nomor 19 Tahun 2018 Tentang Pencatatan Perkawinan menyebutkan Pasal 2 ayat (1) "Perkawinan antara seorang laki-laki dan seorang perempuan beragama Islam wajib dicatat dalam Akta Perkawinan." Pasal 2 ayat (2) Pecatatan perkawinan dalam Akta Perkawinan sebagaimana dimaksud pada ayat (1) dilakukan oleh Kepala KUA Kecamatan."

Pencatatan perkawinan ialah kebijakan dari pemerintah sebagai upaya perlindungan terhadap perkawinan dan memberikan kepastian hukum kepada para pihak yang melakukan suatu perkawinan. Perkawinan wajib dicatatkan agar mendapatkan bukti otentik atas perkawinannya. Perkawinan yang tidak dicatatkan disebut juga sebagai perkawinan sirri yaitu perkawinan yang dilakukan berdasarkan agama saja. Dampak yang timbul dari dilakukannya perkawinan sirri yaitu tidak mendapatkan perlindungan hukum dari negara atas perkawinannya. Perkawinan sirri menurut Hilman yaitu :

"Perkawinan Sirri adalah perkawinan yang dilakukan berdasarkan aturan agama atau adat istiadat dan tidak dicatatkan di Kantor Urusan Agama (yang kemudian selanjutnya disebut KUA) bagi yang beragama Islam, Kantor Catatan Sipil bagi non-Islam."

Dalam perkawinan sirri terdapat akibat hukum yang terhadap orang yang melakukannya, menurut Ali Uraidy menyebutkan akibat hukum yang timbul dari perkawinan sirri yaitu tidak adanya kekuatan hukum terhadap legalitas perkawinan, isteri tidak dapat menuntut haknya secara hukum apabila hak isteri dilanggar oleh suami, suami-isteri yang melaksanakan akad nikah sirri tidak dapat dibuktikan secara hukum, kepentingan suami-isteri dalam menjalan kehidupan berumah tangga tidak dapat dilindungi, tidak dapat membuat Kartu Keluarga (KK), dan akta kelahiran anak, karena tidak adanya bukti sudah melakukan perkawinan. Menurut Pasal 64 Undang-Undang Perkawinan, untuk perkawinan dan segala sesuatu yang berhubungan dengan perkawinan yang terjadi sebelum undang-undang ini berlaku yang dijalankan menurut peraturan-peraturan lama, adalah sah. Pasal tersebut dapat ditasirkan sebagai itsbat nikah yang dilakukan di Pengadilan Agama dan dijelaskan pula dalam UndangUndang Nomor 23 Tahun 2006 Tentang Administrasi Kependudukan Pasal 35 huruf (a) berkenaan dengan pencatatan perkawinan berlaku pula bagi perkawinan yang ditetapkan oleh pengadilan.

Dalam Kompilasi Hukum Islam Pasal 7 menyebutkan,

1. Perkawinan hanya dapat dibuktikan dengan Akta Nikah yang dibuat oleh Pegawai Pencatat Nikah

2. Dalam hal perkawinan tidak dapat dibuktikan dengan Akta Nikah, dapat diajukan itsbat nikahnya ke Pengadilan Agama

3. Itsbat nikah yang dapat diajukan ke Pengadilan Agama terbatas mengenai hal-hal yang berkenaan dengan :

a. Adanya perkawinan yang dalam rangka penyelesaian perceraian

b. Hilangnya Akta Nikah

c. Adanya keraguan tentang sah atau tidaknya salah satu syarat perkawinan

d. Adanya perkawinan yang terjadi sebelum berlakunya Undang-Undang Nomor 1 Tahun 1974 dan

e. Perkawinan yang dilakukan oleh mereka yang tidak mempunyai halangan perkawinan menurut Undang-Undang Nomor 1 Tahun 1974 
Menurut Philipus M. Hadjon :

"Perlindungan hukum adalah perlindungan akan harkat dan martabat manusia, serta pengakuan terhadap hak-hak asasi manusia yang dimiliki oleh subyek hukum berdasarkan ketentutan umum dari kesewangan atau kaidah yang akan dapat melindungi suatu hal lainnya."

Sarana perlindungan hukum ada 2 (dua) yaitu sarana perlindungan hukum preventif, yaitu erat kaitannya dengan azas freis ermessen sebagai bentuk perlindungan hukum secara umum. Kemudian, sarana perlindungan hukum represif yang ditangani oleh badan-badan peradilan, dan instansi pemerintah.

\section{Hasil Penelitian dan Pembahasan}

Perkawinan sirri merupakan perkawinan yang tidak di daftarkan ke KUA. Adapun faktor melakukan perkawinan sirri di Purwakarta yaitu :

1. Persyaratan nikah terhambat, seperti pernikahan dini yang kurang dari 19 tahun dan tidak menempuh dispensasi nikah.

2. Pernikahan yang terhalang, seperti poligami.

3. Status duda atau janda yang perceraiannya di bawah tangan.

Pemerintah Daerah Kabupaten Purwakarta pada tahun 2020 memiliki anggaran sekitar Rp. 270.000.000,- dari anggaran pendapatan dan belanja daerah untuk membantu pasangan suami-isteri agar memiliki akta nikah melalui itsbat nikah. Pada tahun 2019 telah dilakukan itsbat nikah di kecamatan Bojong dan kecamatan Maniis terdapat 249 pasangan suami-isteri yang sudah mengikuti itsbat gratis ini. Alasan pasangan suami-isteri mengikuti itsbat nikah karena pernikahan dini dan tidak melakukan dispensasi nikah.

Itsbat nikah gratis dilakukan dengan tahap berdasarkan usulan dari Kecamatan terhadap Pemerintah Daerah bahwa di Kecamatan tersebut masih banyak yang belum memiliki akta nikah, kemudian dengan pertimbangan yang matang Pemerintah Daerah mengadakan itsbat nikah di Kecamatan tersebut. Itsbat nikah yang dibiayai oleh Pemerintah Kabupaten Purwakarta dalam pelaksanaanya membolehkan bagi masyarakat purwakarta yang belum memiliki akta nikah untuk mengikuti Itsbat nikah.

Tujuan dari diadakannya program itsbat nikah yaitu untuk memberikan perlindungan terhadap perempuan dan anak, karena selain dicatat secara hukum negara, akta nikah yang dikeluarkan setelah melakukan itsbat nikah juga dapat digunakan untuk membantu pasangan suami-isteri dalam pengurusan administrasi. Salah seorang peserta di Desa Bojong Timur mengakui bahwa dirinya terpaksa mendaftar itsbat nikah karena tuntutan ke dua anaknya dari hasil nikah bawah tangan yang membutuhkan akta nikah orang tuanya untuk persyaratan pembuatan akta lahir anaknya.

Program itsbat nikah gratis telah berjalan selama 5 (lima) tahun dan sampai saat ini program tersebut masih berjalan. Namun, dalam pelaksanaanya persidangan itsbat nikah masih terdapat kesalahpaaman terkait saksi yang di hadirkan di dalam persidangan. Saksi yang hadir saat persidangan lebih baik pada saat yang menyaksikan nikah, namun apabila tidak ada maka diperbolehkan dengan membawa saksi yang mengetahui bahwa pasangan suami-isteri pernah menikah. Dalam persidangan berlangsung akan dihadirkan 2 (dua) orang saksi yang mengetahui bahwa pasangan suami-isteri telah menikah, para saksi tersebut akan diajukan beberapa dan Hakim akan mempertimbangkan kesesuaian antara ke-dua saksi mengenai persamaan apa yang diketahui mengenai pasangan suami-isteri tersebut. Sesuai dengan yang dijelaskan dalam Kitab Undang-Undang Hukum Perdata Pasal 1908 yang berbunyi "dalam mempertimbangkan suatu kesaksian, Hakim harus memberikan perhatian khusus, pada kesesuaian kesaksian-kesaksian satu sama lain, pada persamaan antara kesaksian-kesaksian dan apa yang diketahui dan sumber lain tentang pokok perkara, pada alasan-alasan yang kiranya telah mendorong para saksi untuk menerangkan duduknya perkara secara begini atau secara begitu pada peri kehidupan, kesusilaan dan kedudukan para saksi dan umumnya ada apa saja yang mungkin ada pengaruhnya terhadap dapat tidaknya para saksi itu dipercaya." Sehingga, apabila terdapat perbedaan dan tidak sesuai antara ke-dua saksi tersebut maka akan mempengaruhi pertimbangan hakim mengenai para saksi tersebut.

Dalam permohonan itsbat nikah namun bukan untuk yang pertama kali atau dapat 
disebut juga dengan permohonan itsbat nikah poligami atas dasar nikah sirri harus dinyatakan tidak dapat diterima berdasarkan Surat Edaran Mahkamah Agung Nomor 3 Tahun 2018 Tentang Pemberlakuan Rumusan Hasil Rapat Pleno Kamar Mahkamah Agung Tahun 2018 Sebagai Pedoman Pelaksanaan Tugas Bagi Pengadilan III Rumusan Hukum Kamar Agama Huruf A Hukum Keluarga No. 8 yang berbunyi, "permohonan isbat nikah poligami atas dasar nikah siri meskipun dengan alasan untuk kepentingan anak harus dinyatakan tidak dapat diterima. Untuk menjamin kepentingan anak dapat diajukan permohonan asal-usul anak."

Kecamatan Maniis memiliki luas $71.64 \mathrm{~km} 2$ berbatasan dengan waduk cirata, terdapat 33.385 jiwa penduduk, memiliki 8 kelurahan. Kecamatan Bojong memiliki luas $68.69 \mathrm{~km} 2$ dan berbatasan langsung dengan kecamatan kecamatan Pondoksalam dan Kabupaten Bandung. Terdapat 50,724 penduduk dan memiliki 14 kelurahan. Dalam rekapitulasi jumlah peserta pelaksanaan penanganan dokumen pernikahan (isbat nikah) kerjasama pemerintah Kabupaten Purwakarta dengan Pengadilan Agama Kabupaten Purwakarta diperoleh data pada tahun 2019 di Kecamatan Bojong jumlah peserta 470 pasang dan pada tahun 2020 di Kecamatan Maniis jumlah peserta 420 pasang yang mendafatar untuk itsbat nikah. Perkara yang masuk pada tahun 2019 di Pengadilan Agama dari Kecamatan Bojong terdapat 163 Perkara dan di Kecamatan Maniis terdapat 84 perkara. Pada tahun 2020 Kecamatan Maniis terdapat 100 Perkara. Hal, tersebut membuktikan bahwa terdapat verifikasi data untuk dilakukan pengecekan data-data dari para peserta yang mendaftar apakah syarat-syarat untuk mengajukan permohonan mengajukan itsbat nikah sudah terpenuhi atau belum.

Dalam penetapan pengesahan itsbat nikah gratis ini, para Hakim berijtihad pada Pasal 7 ayat (3) huruf e. Hal tersebut dikarenakan poin huruf a,b,c,d tidak terpenuhi. Untuk poin huruf e terpenuhi selama tidak melanggar selama tidak terdapat halangan perawinan menurut UndangUndang Perkawinan. Namun, selama pelaksanaannya para Hakim juga meninjau dan meneliti terlebih dahulu perkaranya.

Dalam hal perkawinan sirri, tidak menjamin adanya perlindungan hukum terhadap perkawinannya, dikarenakan tidak memiliki bukti otentik atas perkawinannya. Maka dari itu, Pemerintah Kabupaten Purwakarta membuat program itsbat nikah gratis bagi masyarakat Purwakarta yang tidak memiliki akta nikah. Itsbat nikah merupakan suatu produk dari Pengadilan Agama dan termasuk ke dalam perlindungan hukum represif. Tujuan dari diadakannya itsbat nikah yaitu selain untuk mendapatkan akta nikah dapat memberikan perlindungan hukum kepada kaum wanita sebagai isteri dan anak-anak dari perkawinannya, karena perkawinannya dapat dicatat oleh negara.

Dalam hal itsbat nikah, dengan dilakukannya pertimbangan hukum dan pemeriksaan alat bukti termasuk saksi maka akan dikeluarkan surat penetapan yang menyatakan perkawinan tersebut sah berdasarkan ketentuan Kompilasi Hukum Islam Pasal 7 ayat (3) dan memiliki kekuatan hukum atas perkawinannya. Selanjutnya, memerintahkan terhadap para pihak untuk mencatatkan perkawinannya kepada Kantor Urusan Agama Kecamatan sesuai dengan ketentuan Undang-Undang Nomor 23 Tahun 2006 Tentang Administrasi Kependudukan. Setelah, dilakukannya pencatatan maka akan dikeluarkan akta nikah yang dapat disimpan oleh para pasangan suami-isteri sebagai bukti otentik atas pernikahannya. Untuk pasang an suami-isteri yang sudah mendapatkan akta nikah, maka dapat mengurus administrasi kependudukan seperti halnya kartu keluarga, akta kelahiran anak untuk memenuhi hak anak atas identitasnya sesuai dengan Pasal 5 Undang-Undang Nomor 23 Tahun 2002 tentang Perlindungan Anak, dan dapat membuat paspor. Serta, terhadap perkawinan yang telah dinyatakan sah melalu itsbat nikah memiliki hubungan hukum antara suami-isteri dan anak-anak yang dilahirkan dari perkawinannya. Maka, berdampak pada adanya hak dan kewajiban yang timbul antara suami kepada isteri, isteri kepada suami, orangtua terhadap anak dan berkenaan dengan harta bersama maupun hak kewarisan.

\section{Kesimpulan}

Berdasarkan permasalahan dan pembahasan yang telah dibahas dalam bab sebelumnya, maka dapat ditarik simpulan sebagai berikut :

1. Implementasi itsbat nikah yang terjadi di Kecamatan Maniis dan Kecamatan Bojong 
sudah sesuai dengan ketentuan Pasal 7 ayat (3) Kompilasi Hukum Islam dan tidak melanggar halangan perkawinan (Pasal 8 Undang-Undang Perkawinan). Namun, untuk saksi yang hadir dalam persidangan itsbat nikah masih terjadi kesalahpamahan dalam hal saksi yang dihadirkan tidak harus saksi dalam akad nikah saja.

2. Perlindungan hukum dilaksanakannya itsbat nikah adalah terlahirnya akta nikah sebagai bukti otentik telah terjadinya perkawinan sah, yang membawa akibat hukum terhadap suami-isteri, anak, dan harta kekayaan.

\section{Daftar Pustaka}

[1] Ikhwanuddin Harahap, Pluralisme Hukum Perkawinan di Tapanuli Selatan, Jurnal Hukum,Vol. 43 No. 1, Januari - Juni, 2019.

[2] Supriyadi, Perkawinan Sirri Dalam Perspektif Hukum di Indonesia, Jurnal Hukum YUDISIA, Vol. 8, No. 1, Juni 2017.

[3] M. Ali Khumaini, Purwakarta Gelar Isbat Nikah Bantu Suami Istri Miliki Buku Nikah, Antara News Megapolitan, https://www.google.co.id/amp/s/megapolitan.antaranews.com/amp/berita/66576/purwakart a-gelar-isbat-nikah-bantu-suami-istri-miliki-buku-nikah

[4] Undang-Undang Perkawinan.

[5] Husni Syawali. 2009. Pengurusan (Bestuur) Atas Harta Kekayaan Perkawinan Menurut KUH Perdata Undang-undang Nomor 1 Tahun 1974 Tentang Perkawinan dan Hukum Islam, Yogyakarta: Graha Ilmu, halaman 4

[6] Zahri Hamid, Pokok-Pokok Perkawinan Islam dan Undang-Undang Perkawinan Indonesia, Binacipta, Yogyakarta, 1976, Kompilasi Hukum Islam.

[7] Ahmad Rofiq, Pembaharuan Hukum Islam di Indonesia, Gama Media, Yogyakarta, 2001.

[8] Ali Uraidy, Perkawinan Sirri dan Akibat Hukumnya Ditinjau dari Undang-Undang No. 1 Tahun 1974, Jurnal Ilmiah Fenomena, Vol. X, No. 2, November 2012.

[9] Farida Nurun Nazah, Kepastian Hukum Itsbat Nikah Dalam Hukum Perkawinan, Jurnal Hukum, Vol. 6, No. 2, September 2018.

[10] Philipus M. Hadjon, Perlindungan Hukum bagi Rakyat, PT. Bina Ilmu, Surabaya, 1987. 